\title{
Development of guidance for sustainable irrigation use of greywater in gardens and small-scale agriculture in South Africa
}

\author{
N Rodda ${ }^{1 *}, \mathrm{~K}_{\text {Carden }}{ }^{2}$, N Armitage $^{2}$ and HM du Plessis ${ }^{3}$ \\ ${ }^{1}$ School of Biological and Conservation Sciences, University of KwaZulu-Natal (Westville Campus), Private Bag X54001, \\ Durban 4000, South Africa \\ ${ }^{2}$ Department of Civil Engineering, University of Cape Town, Cape Town, South Africa \\ ${ }^{3}$ Water Research Commission, Pretoria, South Africa
}

\begin{abstract}
Greywater is untreated household effluent from baths, showers, kitchen and hand-wash basins and laundry (i.e. all non-toilet uses). More than half of indoor household water is normally used for these purposes and can potentially be intercepted by the householder for additional beneficial uses. Greywater use is practised on an informal basis to supplement irrigation water, either in urban gardens in middle- to upper-income suburbs or in food gardens in lower-income informal, periurban and rural areas. It holds the potential to contribute significantly to food security in poor settlements by providing a source of both irrigation water and nutrients for crop plants. However, there are presently no formal guidelines for the use of greywater in South Africa. This paper presents the rationale and framework of a guidance document for the sustainable use of greywater to irrigate gardens and small-scale agriculture in South Africa, developed under the auspices of the Water Research Commission. The 3 driving principles in developing this guidance were: protection of human health; protection of plants irrigated; and protection of soil and the environment. Risk-management scenarios were developed on the basis of the extent of greywater characterisation. Water-quality constituents for inclusion were selected from among those indicated as presenting a problem in previous studies. Guidance was provided for managing greywater quality, either by mitigation of greywater quality (by practices such as irrigation method, amelioration of soil, leaching of soil and planting of tolerant plant types) or by small-scale biological treatment of greywater. Guidance was also given regarding the volumes of greywater which can be applied, together with factors to adjust these volumes for site-specific conditions.
\end{abstract}

Keywords: greywater, irrigation, food security, sustainable agriculture, health, soil, plant growth

\section{Introduction}

South Africa is a water-scarce country, with about $65 \%$ of the country receiving an average annual rainfall of less than $500 \mathrm{~mm}$, which is normally considered to be the minimum required for rain-fed cropping (Schulze, 1997). South Africa also faces increasing pressure on limited freshwater sources, which are increasingly threatened by point and non-point source pollution, all of which means that new sources of water need to be sought.

Innovative approaches are required to preserve both the quantity and quality of existing water supplies. Concepts such as ecological sanitation (EcoSan) have arisen to address this need. The underlying principle of EcoSan is that domestic waste should be seen as a potential resource for further use to recover water and plant nutrients that would otherwise be lost through discharge to the environment (Winblad and SimpsonHébert, 2004). Greywater is untreated household wastewater from baths, showers, kitchen and hand-wash basins, and laundry (i.e. all non-toilet uses). Using this water sustainably for irrigation in small-scale agriculture and in gardens is one possible way of alleviating water stress (Murphy, 2006). Since greywater contains some nitrogen and phosphorus (Eriksson et al., 2002; Morel and Diener, 2006), it is also a potential source of nutrients for plant growth, particularly for users who cannot

This paper was originally presented at the Water Research

Commission 40-Year Celebration Conference, Kempton Park,

31 August - 1 September 2011.

* To whom all correspondence should be addressed.

용 +27 (31) 260-3015; fax: +27 (31) 260-2029;

e-mail: roddan@ukzn.ac.za afford fertiliser. In the same vein, the soapy nature of greywater means that under some conditions it has pest-repellent properties, again of particular significance to users who cannot afford pesticides. In view of seasonal water restrictions in many parts of the country, and perennial poverty in low-income settlements, the use of greywater to supplement irrigation water is attractive. It is already practised on an informal basis in urban gardens in middle- to upper-income suburbs in times of drought, or in food gardens in lower-income informal, periurban and rural areas. Greywater irrigation holds the potential to contribute significantly to food security in poor settlements by providing a source of both irrigation water and nutrients for cultivating crop plants. Where crops are produced in excess of household needs and can be sold or exchanged for other goods or services, it further holds the potential for informal employment. Facilitating small-scale agriculture in these settlements contributes not only to nutrition, but also to social structure (Van Averbeke, 2007).

\section{Existing practices and guidelines for greywater use}

Greywater treatment and its use for irrigation and other purposes have been reported in relatively high-income, developed countries such as USA, UK, Australia, Germany and Sweden (Roesner et al., 2006), and in less developed, low-to-middle income countries such as Costa Rica, Jordan, Malaysia, Mali, Nepal, Palestine and Sri Lanka (Morel and Diener, 2006). Thus although individual greywater-use applications are usually small and varied in their design, the concept of greywater use for irrigation to promote water conservation and use of the 
associated nutrients is not new. Despite this, formal standards or quantitative guidance for the quality of greywater for reuse are not widely available. However, there is an increasing wealth of qualitative guidance obtainable on the Internet, from water authorities, from non-governmental organisations (NGOs), from manufacturers of greywater treatment systems, and from professionals in the field, regarding precautions to be taken in the application of greywater for irrigation. Examples include guidelines available in Australia (Standen and McGuckian, 2000; EPA Victoria, 2008), Jordan (CSBE, 2003), Sweden (Ridderstolpe, 2004) and the USA (Little, 2001).

In South Africa, the National Water Act (NWA) of 1998 is the major piece of legislation addressing the use and disposal of water. The Act makes no specific reference to greywater, but refers to 'disposal of waste or water containing waste'. Discharge or use of water containing waste requires that the use is listed in a General Authorisation (GA) of the Act or alternately requires issue of a licence. General Authorisations provided under the NWA were revised in 2004 to allow, amongst others, limited use of biodegradable industrial wastewater for irrigation (DWAF, 2004). Although greywater is not mentioned among the types of wastewater considered, this is probably the closest that existing legislation comes to providing guidance for quality of greywater intended for irrigation use.

The Department of Water Affairs, the Government department tasked with implementation of the NWA, has indicated that it supports single-household use of greywater for irrigation as a water-saving measure, provided this poses no health or pollution hazards. The authorisation for this is considered to be implicitly provided under permitted water uses specified in Schedule 1 of the NWA. Although greywater use for smallscale irrigation is not mentioned, it is considered to be within the spirit of the law. For larger-scale use, either the requirements under the GAs apply as mentioned above, or a licence for this use would have to be obtained (Gravele't-Blondin, 2010).

Other national legislation and policies which reference wastewater in some manner include the National Building Regulations (NBR) in terms of the National Building Regulations and Building Standards Act (Act No. 103 of 1977) (Resolve Consulting, 2010), guidelines for the use of wastewater for irrigation (Department of Nationsl Health and Population Development, 1978) and the National Policy on Sanitation (DWAF, 2003). None of these addresses greywater and consequently by implication excludes greywater use from legally recognised water uses. Some local authorities, e.g. Cape Town Municipality, have introduced policies and by-laws (currently in draft form), which provide guidance relevant to the management and use of greywater for irrigation, either explicitly or implicitly (Carden et al., 2007). However, the status of such guidance remains in doubt as long as the legislative status of greywater use is not clarified.

Thus, existing legislation in South Africa does not specifically exclude use of greywater for irrigation, but there are inconsistencies which arise from the absence of a clear definition of greywater as a subset of domestic wastewater which can be separated at source and which differs in character and hazards from blackwater (sewage). These need to be resolved to clarify the legal position of use of greywater for irrigation. The development of guidance for irrigation use of greywater constitutes a step along the way to introducing greywater use as a formally recognised beneficial use of this waste stream.

Guidelines for any form of water use are intended to address risks associated with that use. With reference to greywater use for small-scale irrigation applications, concerns about risk fall into 3 categories:

- Possible adverse effects on human health

- Possible adverse effects on plant growth and yield

- Possible adverse effects on the environment, especially on the continued ability of the soil to support plant growth.

\section{Possible adverse effects on human health}

Greywater contains micro-organisms from skin surfaces and dirt; small amounts of urine and faeces (e.g. from washing of soiled nappies or bedclothes); and washing and preparation of food. Standing greywater provides an environment in which micro-organisms can survive and proliferate (Eriksson et al., 2002; WHO, 2006). As a result, greywater usually contains relatively high numbers of micro-organisms, some of which may be capable of causing disease in those who come into contact with the greywater or with plants and crops irrigated with greywater, particularly consumers of greywater-irrigated produce (WHO, 2006).

\section{Possible adverse effects on plant growth and yield, and on the continued ability of the soil to support plant growth}

Greywater also contains substances that can reduce plant growth or crop yield if present at sufficiently high concentrations. These include salts (e.g. used as bulking agents in detergents), sodium and boron. Furthermore, extremes of $\mathrm{pH}$, which may be encountered in laundry greywater, can be damaging to plants (Eriksson et al., 2002; Morel and Diener, 2006). Some constituents of greywater can change soil properties so that soil becomes progressively less fertile (i.e. less able to support plant growth). Because soil properties change slowly, these tend to be long-term effects, while effects on plant growth and yield are more short-term. The major concerns with regard to soil are salinity and sodicity, both of which are related to the concentration of sodium in greywater (DWAF, 1996; Unkovich et al., 2004). Other greywater constituents which may affect soil adversely are detergents, oil and grease, and suspended solids (Eriksson et al., 2002; Travis et al., 2008).

\section{Interdependence of quality and quantity of greywater}

The quality of greywater is closely linked to the quantity of greywater generated, both on a household scale and on a community scale. The amount of greywater generated per household varies greatly, being lowest in low-income households $\left(20 \ell \cdot \mathrm{d}^{-1}\right.$ to $\left.30 \ell \cdot \mathrm{d}^{-1}\right)$ and highest in households with in-house taps and an affluent lifestyle (Morel and Diener, 2006). The mean greywater return in un-sewered settlements in South Africa is $75 \%$ of household water consumption (Carden et al., 2007).

The high housing density in un-sewered settlements generally corresponds to a high overall greywater generation in the settlement, even when the volume of water used per dwelling is relatively low. Combined with the high concentration of pollutants in greywater in informal settlements, the lack of proper waste and wastewater infrastructure and the widespread mingling of different waste streams, this has led to doubts concerning the possibility of the safe use of greywater in these settlements (Carden et al., 2007). The paradox is that greywater offers the greatest potential for improvement in household nutritional status and social functioning in poor rural settlements, and in urban and peri-urban settlements around the major metropoles of South Africa (Van Averbeke, 2007). The 
challenge, then, lies in identifying conditions and limitations under which greywater could potentially be used beneficially in such settlements.

This paper reports on an interrelated series of investigations, conducted under the auspices of a project solicited by the Water Research Commission aimed at addressing the potential and problems of greywater use in small-scale irrigation, and reported in 2 recent WRC reports (Rodda et al., 2010a; b). The objective of the project was to produce a user-friendly guidance document for greywater use in gardens and small-scale agriculture in South Africa which could aid users in planning and implementing greywater irrigation in a safe and sustainable manner. The guidance was developed on the basis of published literature, user consultation, outcomes of a number of supporting studies and peer review through the WRC reference-group system. This paper focuses on the format and content of the guidance report produced. It does not report in detail on any of the supporting consultations or studies that contributed to it.

\section{Methodology}

\section{Literature review}

National and international literature was surveyed to identify existing knowledge and key issues relating to standards, guidelines and advice on the use of greywater for irrigation. Existing WRC projects, peer-reviewed literature, legislation and guidelines, technical reports and 'grey' literature were used as sources. Based on the outcome of this literature review, the status of greywater legislation in South Africa was defined and the principles to be addressed in guidance developed were indentified. Knowledge gaps were also identified, and case studies to address these knowledge gaps were initiated. These included several desk studies of existing data on greywater quality, quantity, generation and use; surveys of local authorities and potential greywater users; and 3 experimental studies.

\section{Supporting studies}

Two experimental studies focused on irrigation of crop plants with untreated greywater from an informal settlement (Cato Manor, Durban). One study followed plant growth and yield, and chemical constituents of leaves, crops and soil. The $2^{\text {nd }}$ study evaluated the microbiological quality of plants and crops, and estimated the health risks associated with crop consumption with and without a number of exposure barriers. The $3^{\text {rd }}$ experimental study evaluated a biological treatment system for greywater, comprising an above-ground mulch tower and subsurface infiltration zone and resorption bed. This was based on greywater treatment systems piloted in Kimberley and East London (Ridderstolpe, 2007; Whittington-Jones, 2007). All 3 studies are described in full in Rodda et al. (2010b), and separately in Jackson et al. (2006; 2010), Naicker et al. (2010) and Rodda et al. (2011). All 3 studies were co-funded by other agencies in addition to funding provided by the WRC.

\section{Consultative process}

Up-front consultation was undertaken with policy-makers, local authorities and potential greywater users to identify the state of knowledge and opinion surrounding greywater use at different levels. Several methods were used. An exploratory workshop was held with policy-makers, while local authorities were surveyed by a questionnaire sent out to all local authorities listed by the South African Local Government Association (SALGA). Existing surveys of greywater generation, use and disposal in un-sewered settlements (Carden et al., 2007), were supplemented by surveys of 6 settlements served either by waterborne sewerage or by dry on-site sanitation.

The completed draft guidance report was submitted for review by the reference group. A feedback and capacitybuilding workshop was held for local authorities, in which the guidance report was presented and feedback was solicited. Policy-makers were invited to participate in the workshop or otherwise to provide comment. All feedback was incorporated in the guidance report (Rodda et al., 2010a) and the accompanying technical report (Rodda et al., 2010b).

\section{Guide to managing risks and uncertainty}

The conceptual framework of the most recent World Health Organisation (WHO) Guidelines for the Safe Use of Wastewater, Excreta and Greywater (WHO, 2006) was applied. These Guidelines recognise that risk exists only where there is both a hazard and exposure to that hazard; thus risk can be reduced either by improving the quality of the greywater (removing or reducing hazards) or by imposing barriers to exposure (preventing exposure to the hazards). On this basis, 3 risk and uncertainty categories were identified among potential users of greywater for irrigation:

- Category 1: Users unable or unwilling to conduct any analyses to characterise greywater quality prior to planning irrigation use and during its implementation.

- Category 2: Users willing and able to conduct limited analyses (minimum analysis) to characterise greywater quality prior to planning irrigation use and during its implementation. Minimum analysis was defined as $\mathrm{pH}$, electrical conductivity (EC), sodium adsorption ratio (SAR) and faecal coliforms / E. coli.

- Category 3: Users willing and able to conduct more extensive analyses (full analysis) to characterise greywater quality prior to planning irrigation use and during its implementation. Full analysis was defined as minimum analysis plus boron, chemical oxygen demand (COD), oil and grease, suspended solids, total inorganic nitrogen and total phosphorus.

The higher the magnitude of the hazard (i.e. the poorer the quality of the greywater), the more stringent the required riskmanagement interventions will have to be to protect human health, plants and soil. Risk-management interventions related to exposure were described as barriers which minimise the exposure of human users, plants or soil to a given hazard, based on the following rationale. As the extent of analysis increases from Category 1 to Category 3 - and, by implication, as greywater quality improves as it complies with the quality guidance associated with the analysis - so the magnitude of the hazard decreases, and hence so do the risk-management requirements. Where analysis results are in excess of the quality guidance, either steps can be taken to improve greywater quality, or the more restrictive exposure limits of the preceding category can be accepted. If analysis indicates that the greywater is totally unsuitable for use, then greywater irrigation should be avoided.

As an example of barriers to exposure, the case study on health risks associated with consumption of greywater-irrigated crops demonstrated that personal hygiene and food-preparation methods, such as washing hands and peeling and cooking vegetables, could reduce health risk to acceptable levels (Jackson 
et al., 2006; 2010; Rodda et al., 2010b). This makes it possible for consumers to take advantage of improved levels of nutrients in food crops irrigated with mixed domestic greywater (Rodda et al., 2010b; Rodda et al., 2011).

Using this categorisation of risk and uncertainty, flowcharts were developed to guide users through decisions associated with each risk-management category, leading to a table of restrictions on use for each category.

\section{Greywater quality: Guide to greywater constituents}

The constituents for inclusion in the quality section of the guidance report were selected from among those found to be consistently in excess of various guidelines in a number of studies of greywater quality in South Africa, mainly from un-sewered areas (Carden et al., 2007; Rodda et al., 2010b), but also including a limited survey of greywater from various sources in sewered households (Rodda et al., 2010b). The list of constituents was consolidated to include only those considered of greatest relevance to use of greywater for irrigation and congruent with the underlying principles of the guidelines (protection of human health, of plant growth and yield, and of soil fertility).

The precautionary principle implemented in a qualitative manner in the South African Water Quality Guidelines (SAWQG) for irrigation (DWAF, 1996), and in a quantitative manner in the WHO Guidelines for Human Health Risks (WHO, 2006), was also applied to the development of guidance for the use of greywater in small-scale irrigation. This included a graded series of quality ranges, indicating preferred quality (target range), tolerable quality (maximum range), quality which can be used on a site-specific basis for a limited time and with special precautions (short-term use on site-specific basis only), or quality which is not considered suitable for irrigation use unless treated (not recommended for irrigation use). Limit values for greywater constituents were derived wherever possible from the SAWQG for agricultural irrigation, since these represent a body of collected wisdom on water quality for irrigation, adapted for South African conditions. Where constituents were not available in the SAWQG, other guidelines and available literature were consulted.

\section{Greywater quality: Mitigation of greywater quality}

Two complementary approaches were presented in the guidance for situations in which greywater quality required improvement to extend its suitability for irrigation. Integrated mitigative practices aim to minimise potential adverse effects of, primarily, physicochemical greywater components (such as EC, SAR, sodium, boron) as part of plant/crop cultivation. Treatment systems aim to remove, primarily, suspended solids, oil and grease, chemical oxygen demand (COD) and healthrelated bacteria from greywater. Treatment options were based on pilot projects which have been conducted in South Africa and all represent forms of biological treatment. These systems may be separate from the irrigation application or integrated with the irrigation application.

\section{Greywater quantity: Guide to irrigation volumes}

Suggested irrigation volumes were estimated using Eq. (1) which is essentially the same as that presented by Green (1985) for calculation of agricultural water use and which is used internationally for estimating landscape irrigation requirements (Bennet, 1995): where:

$E W U=$ maximum estimated water use (measured in $\left.\ell \cdot \mathrm{d}^{-1}\right)$

$E_{0}=$ reference evapotranspiration rate (locationspecific and season-specific; a meteorologicallyderived measure, measured in $\mathrm{mm} \cdot \mathrm{d}^{-1}$ )

$C F=$ crop factor, a measure of plant-specific water use (a unit-less ratio)

$H A=$ area to be irrigated (measured in $\mathrm{m}^{2}$ )

$E W U$ represents only the amount of water required by the plant in light of climatic conditions such as solar radiation, windspeed etc. It does not include other factors which modify plantwater use and thus represents the maximum amount of water which should be applied.

A look-up table of maximum estimated water use, $E W U$, for various regions of South Africa, was developed. To derive this table, it was necessary to use some means of identifying climatic zones throughout the country. A clustering based on mean rainfall and temperature data from 1970 to 2006 was adopted (Blignaut et al., 2009). In South Africa, reference evaporation, $E_{0}$, is measured by pan evaporation and is independent of plant or crop type. Summer and winter values of $E_{0}$ for each of the identified climatic regions were derived from tables of historical data commonly used by agriculturists and farmers to estimate irrigation water requirements for large-scale agriculture (Green, 1985). Representative weather stations were selected from those represented in Green (1985) such that the range of $E_{0}$ values in each of the identified climatic zones was broadly represented. Theoretical values were used for crop factors, $C F$. A value of 0.8 was used to represent high water use, 0.5 to represent moderate water use, and 0.3 for low water use. Representative irrigated areas, $H A$, of $5 \mathrm{~m}^{2}, 10$ $\mathrm{m}^{2}$ and $20 \mathrm{~m}^{2}$ were used. The values for $C F$ and $H A$ used were based on a previous similar general estimation of $E W U$ derived for landscape gardening in California, USA (Bennet, 1995; Murphy, 2006).

\section{Results and discussion}

\section{Underpinning principles for the development of guidance for greywater use in South Africa}

Based on the information obtained from the literature review and the up-front consultative process, the anticipated users and the underlying principles of the guidance developed were defined (Rodda et al., 2010a).

The intended users were identified as:

- Informed members of the public who wish to plan for irrigation use of greywater on their properties or in their communities

- Municipalities needing to guide and monitor greywaterirrigation implementations

The principles underlying the development of the guidance report were:

- Minimisation of risks of illness in handlers of greywater and greywater-irrigated produce, or consumers of greywater-irrigated produce

- Minimisation of risks of reduction in growth or yield in plants/crops irrigated with greywater

- Minimisation of risks of environmental degradation, 


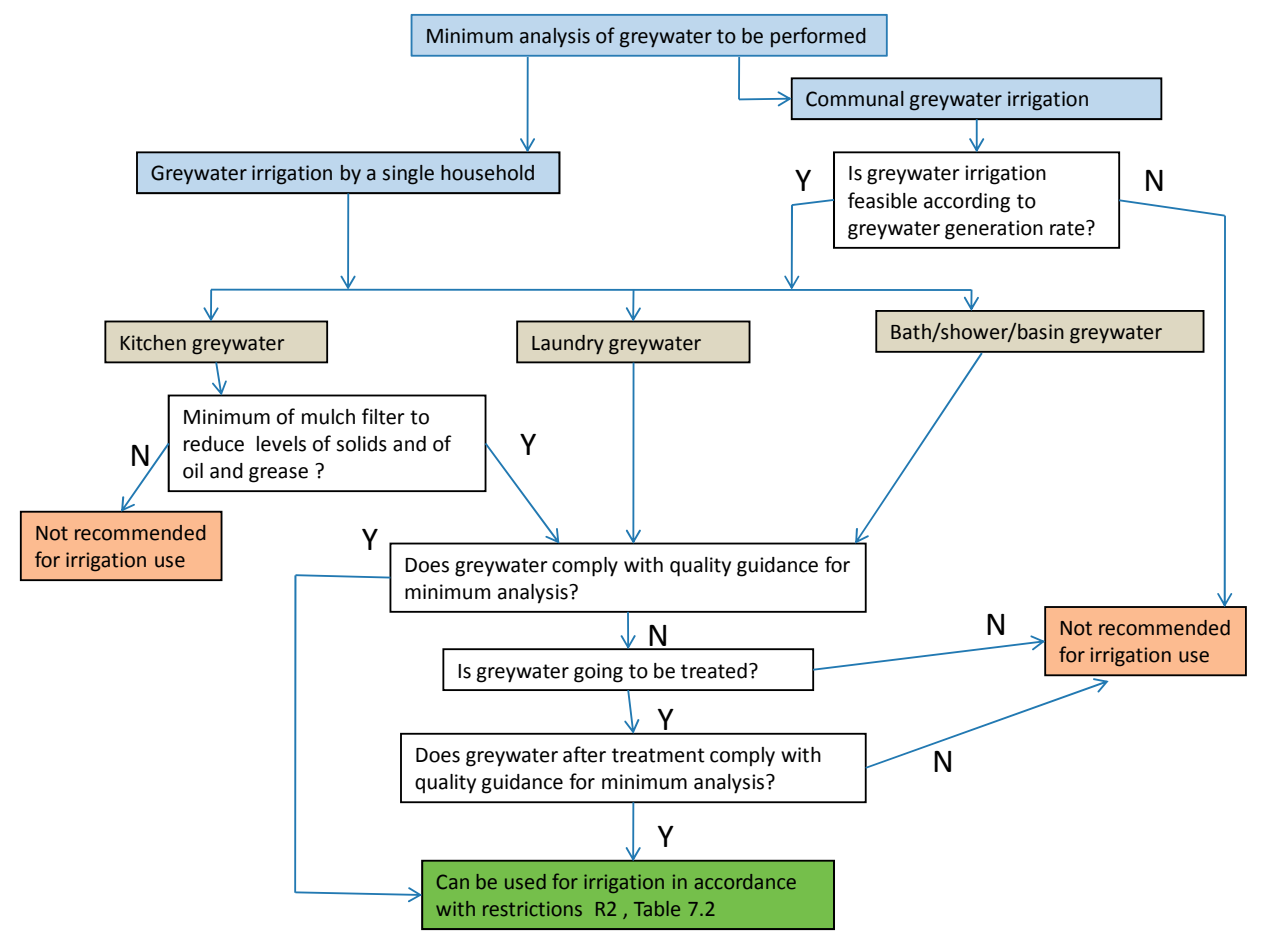

Figure 1

Decision flowchart for management of risks associated with irrigation use of greywater after minimum analysis $(\mathrm{pH}$, electrical conductivity, sodium adsorption ratio, E. coli). Table 7.2 referred to in the figure leads to an accompanying table of restrictions, resembling Table 1 presented here, but presenting restrictions for greywater subjected to minimum analysis.

specifically reduction in the ability of soil irrigated with greywater to support plant growth

An obvious omission would appear to be explicit mention of contamination of surface water bodies under the third point. This is because greywater irrigation is intended to retain all greywater use within the boundaries of the irrigated property. For this reason, the broader environment beyond the irrigated property was not explicitly mentioned in the guidance report. However, to guard against the possibility that greywater does escape from the property, greywater quality guidance ranges were set sufficiently conservatively to provide protection of the surrounding environment, particularly other water bodies.

The following boundary conditions applied to the guidance produced:

- It was intended to address irrigation use of greywater only, not to provide a general solution for disposal of greywater. Thus the focus was not on maximising the volume of greywater which can be applied to land, but on minimising risks and maximising benefits associated specifically with irrigation use of greywater.

- It was intended to be used within the context of existing knowledge and best practice relating to irrigation, e.g. selection of plants, installation and maintenance of irrigation equipment, and adaptation of irrigation schedules to local agro-climatic and soil conditions. The focus was not on providing a catch-all manual for small-scale irrigation implementations, but on managing the additional risks and challenges arising out of the use of greywater in such implementations.

The guidance report emanating from the process described comprised 4 sections, as follows, the development of each of which was described in the Methodology section:

- Guide to managing risks and uncertainty

- Greywater quality: Guide to greywater constituents

- Greywater quality: Mitigation of greywater quality

- Greywater quantity: Guide to irrigation volumes
The outcomes for each section are described in greater detail below.

\section{Guide to managing risks and uncertainty}

Risk, whether expressed qualitatively or quantitatively, indicates the probability of a defined adverse effect occurring in an exposed population. Within the context of the guidance report, the adverse effects and exposed 'populations' were as follows:

- Illness in human handlers of greywater and greywaterirrigated produce, or human consumers of greywaterirrigated produce

- Reduction in plant growth or yield in plants or crops irrigated with greywater

- Environmental degradation, specifically reduction in ability of the soil irrigated with greywater to support plant growth in the long term

Uncertainty refers to the degree of confidence associated with an estimate of risk. In the context of greywater quality, this relates largely to the degree of confidence associated with knowledge of water quality, as once the quality of the greywater is known, suitable steps can be taken to address the risks described above. It should be noted that the baseline of uncertainty associated with greywater use is inherently higher than that associated with, e.g. domestic water use or recreational water use, since greywater is inherently highly variable in quality. Greywater-irrigation implementations are also most likely to occur on a small scale, where frequent monitoring of greywater quality is likely to be economically and logistically difficult.

It is within this context that the 3 risk and uncertainty categories described in the Methodology section were identified. The flowchart for Category 2 is presented in Fig. 1 and the table of restrictions for Category 1 is given in Table 1, as examples of the risk and uncertainty management guidance developed. The restrictions represent barriers to exposure of human users, plants or soil to specific hazards. As the knowledge of 


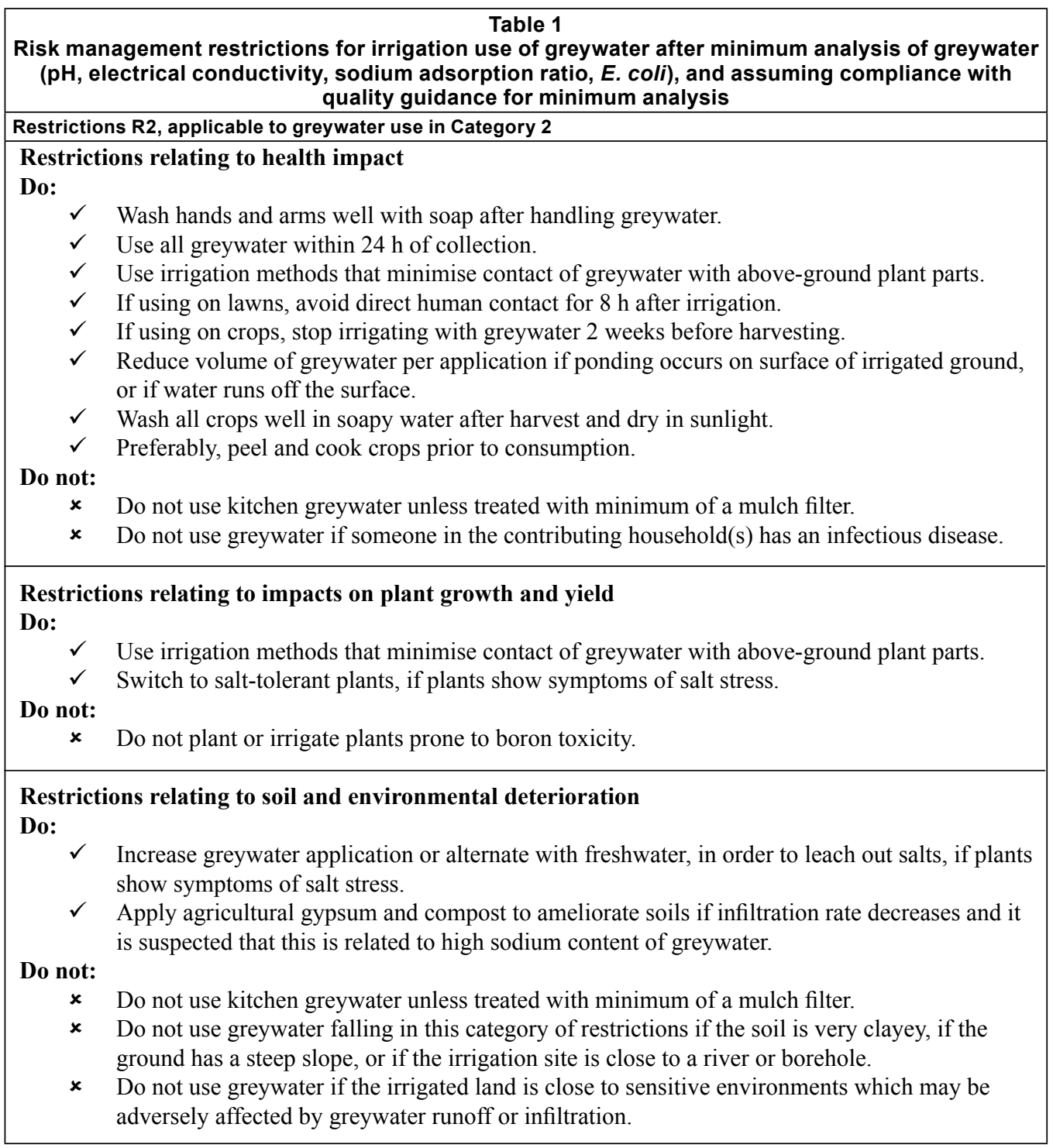

greywater quality improves (from Category 1 to Category 3), so restrictions apply more to the quality of the greywater and less to the way in which it is used. It is assumed that, where analysis of greywater is performed, it is used only if quality falls within the quality guidance provided. Thus Category 1 represents almost no knowledge of greywater quality and stringent risk management in terms of exposure barriers, whereas in Category 3 a significant proportion of the risk-management effort is directed at the quality of the greywater and exposure barriers are accordingly less restrictive.

The restrictions given in Table 1 and in the similar tables in the guidance report for Categories 1 and 3, resemble the precautions given in some existing guidelines for greywater use, such as the 'greywater do's and don'ts' published by the State of New South Wales, Australia (EPA Victoria, 2008) and the 'best management principles' published by the State of Arizona, USA (Arizona Department of Environmental Quality, 2001). These were identified as a useful point of departure in developing similar precautions for use in South Africa. More restrictive legislation placing severe limits on the types of greywater use, levels of treatment and permitting of infrastructure, such as those in force in California, USA (California Building Standards Commission, 2010), were considered to be impractical in the South African context and were not considered.

\section{Greywater quality: Guide to greywater constituents}

The section on greywater quality provides the quality criteria against which measured greywater constituents are compared in risk management Category 2 (minimum analysis) and Category 3 (full analysis) from the preceding section.

The table of quality limits derived according to the approach outlined in the Methodology section is presented in Table 2.

Nitrogen and phosphorus represented exceptions to the philosophy underlying selection of the guidance ranges. It was recognised that nitrogen and phosphorus in greywater are, in the first instance, an opportunity to supplement the nutrient requirements of plants. Both nitrogen and phosphorus are essential plant macronutrients. They are required throughout the lifespan of a plant, but especially at times of growth and development. The guideline ranges recognise that for poor farmers, fertiliser application may be economically infeasible and that greywater used for irrigation is a de facto fertiliser. It was shown that mixed domestic greywater from an informal settlement had the potential to increase both growth and 
Table 2

\begin{tabular}{|c|c|c|c|c|}
\hline \multirow[t]{2}{*}{ Greywater constituent } & $\begin{array}{c}\text { Target water-quality } \\
\text { range }\end{array}$ & $\begin{array}{c}\text { Maximum water- } \\
\text { quality range } \\
\text { (applicable only } \\
\text { to well-drained, } \\
\text { chemically stable } \\
\text { soils) }\end{array}$ & $\begin{array}{l}\text { Water quality suitable only } \\
\text { for short-term use on site- } \\
\text { specific basis. }\end{array}$ & $\begin{array}{l}\text { Water quality not } \\
\text { recommended for } \\
\text { irrigation use }\end{array}$ \\
\hline & $\begin{array}{c}\text { Suitable for } \\
\text { unrestricted use } \\
\text { with minimal risk } \\
\text { to human health, } \\
\text { plants or soil }\end{array}$ & $\begin{array}{l}\text { Increasing risk } \\
\text { to human health, } \\
\text { plants or soil }\end{array}$ & $\begin{array}{l}\text { Significant risk to human } \\
\text { health, plants or soil; } \\
\text { tolerable for short-term } \\
\text { use only }\end{array}$ & $\begin{array}{l}\text { Excessive risk } \\
\text { to human health, } \\
\text { plants or soil }\end{array}$ \\
\hline \multicolumn{5}{|l|}{ Physical constituents } \\
\hline Electrical conductivity $\left(\mathrm{mS} \cdot \mathrm{m}^{-1}\right)$ & $<40$ & $40-200$ & $200-540$ & $>540$ \\
\hline Oil and grease $\left(\mathrm{mg} \cdot \ell^{-1}\right)$ & $<2.5$ & $2.5-10$ & $10-20$ & $>20$ \\
\hline $\mathrm{pH}$ & $6.5-8.4$ & $6-9$ & $6-9$ & $<6>9$ \\
\hline Suspended solids $\left(\mathrm{mg} \cdot \ell^{-1}\right)$ & $<50$ & $50-100$ & $>100$ & $>100$ \\
\hline \multicolumn{5}{|l|}{ Chemical constituents } \\
\hline Boron $\left(\mathrm{mg} \cdot \ell^{-1}\right)$ & $<0.5$ & $0.5-4.0$ & $4.0-6.0$ & $>6.0$ \\
\hline Chemical oxygen demand (COD, $\left.\mathrm{mg} \cdot \ell^{-1}\right)$ & $<400$ & $400-5000$ & $>5000$ & $>5000$ \\
\hline Sodium adsorption ratio ${ }^{2}$ (SAR) & $<2.0$ & $2.0-5.0$ & $5.0-15.0$ & $>15.0$ \\
\hline Total inorganic nitrogen $\left(\mathrm{mg} \cdot \ell^{-1}\right)$ & $<10$ & $10-20$ & $20-60$ & $>60$ \\
\hline Total phosphorus $\left(\mathrm{mg} \cdot \ell^{-1}\right)$ & $<10$ & $10-15$ & $15-50$ & $>50$ \\
\hline \multicolumn{5}{|l|}{ Microbiological constituent } \\
\hline $\begin{array}{l}\text { E. coli } \\
\text { (colony-forming units, CFU·100 } \mathrm{m}^{-1} \text { ) }\end{array}$ & $<1$ & $\begin{array}{c}1-10^{3} \\
(1-1000)\end{array}$ & $\begin{array}{c}10^{3}-10^{5} \\
(1000-100000) \\
\text { Note: Only with appropriate } \\
\text { exposure restrictions - see } \\
\text { text. Range can be extended } \\
\text { to } 10^{7}(10000000) \text { if irriga- } \\
\text { tion is sub-surface. }\end{array}$ & $\begin{array}{c}>10^{7} \\
(>10000000)\end{array}$ \\
\hline
\end{tabular}

${ }^{1}$ Treatment to maximum range (at minimum) is the preferred option.

If this is not sustainable in the long term, then disposal to a sewer should be considered.

${ }^{2}$ Sodium adsorption ratio:

$\mathbf{S A R}=[\operatorname{sodium}] / \sqrt{([\text { calcium }]+[\text { magnesium }]) / 2}$

(2)

All concentrations measured in $\mathrm{mmol} \cdot \ell^{-1}$. SAR is reported without units.

yield of crops relative to tap water, although yield appeared to be boosted less than growth (Rodda et al., 2011). Therefore the ranges of nitrogen and phosphorus presented in the guidance report consider both the fertiliser potential of greywater and the need to supplement greywater with nutrient-poor irrigation water when nutrient concentrations are likely to exceed the requirements of irrigated plants. Maximum beneficial applications of $200 \mathrm{~kg}$ nitrogen $\mathrm{ha}^{-1} \cdot \mathrm{y}^{-1}$ applied in a total of $1000 \mathrm{~mm}$ water $\cdot \mathrm{ha}^{-1} \cdot \mathrm{y}^{-1}$, and $150 \mathrm{~kg}$ phosphorus $\cdot \mathrm{ha}^{-1} \cdot \mathrm{y}^{-1}$ applied in a total of $1000 \mathrm{~mm}$ water $\mathrm{ha}^{-1} \cdot \mathrm{y}^{-1}$ were assumed. In practice the actual application rates are likely to be lower since an irrigation application of $1000 \mathrm{~mm}$ water $\cdot \mathrm{ha}^{-1} \cdot \mathrm{y}^{-1}$ is seldom required under South African conditions. The nitrogen application for small-scale irrigation is supported by studies such as that of Van Averbeke et al. (2007) on African leafy vegetables. While the phosphorus application is high in the light of studies such as Van Averbeke et al. (2007), it was deemed acceptable in view of the fact that most African (including South African) soils are phosphorus-deficient with a high phosphate fixing capacity (Cordell et al., 2009), the relatively high applications that are required to reach phosphorus levels toxic to plants (Siqua et al., 2010; Daniels et al., 2011) and the generally low risk of groundwater contamination (Siqua et al., 2010). Where soils are sandy and there are surface water bodies in the vicinity, thereby increasing the risk of leaching to groundwater and surface water, the volume of water should be limited to that which can be absorbed by plants and soil (no leaching) and the application method should be adapted, both as described in the section on Greywater Quantity.

Microbiological constituents, represented by E. coli, also deserve further mention. The target range $(<1$ colony-forming units (CFU) $\left.100 \mathrm{~m}^{-1}\right)$ and maximum range $(<1000 \mathrm{CFU} \cdot 100$ $\mathrm{m}^{\ell^{-1}}$ ) were sourced from the SAWQG (DWAF, 1996) and similar guidelines. Greywater falling within these ranges can be used with only basic hygiene precautions. However, based on surveys of greywater quality (Carden et al., 2007; Rodda et al., 2010b), it is unlikely that most greywaters would fall within either of these ranges. Results of the experimental study on health risks associated with greywater irrigation showed that greywater containing high levels of $E$. coli and other indicator bacteria could be used to irrigate crops without increasing health risks above acceptable levels, provided that exposure barriers were put in place. These included protective clothing and washing for users of wastewater, and processing steps such as peeling and cooking for the consumers of irrigated produce. Thus the range for short-term use allows for use of greywater with much higher levels of $E$. coli. For this single constituent 'short-term use only' should more correctly read 'use with exposure restrictions only'. The proviso is in the table entry (Table 2).

In assessing greywater for suitability for irrigation use, constituent values should preferably comply with the target limits, but certainly be within the maximum limits (with the 


\begin{tabular}{|c|c|c|c|c|c|c|c|c|}
\hline \multicolumn{9}{|c|}{ 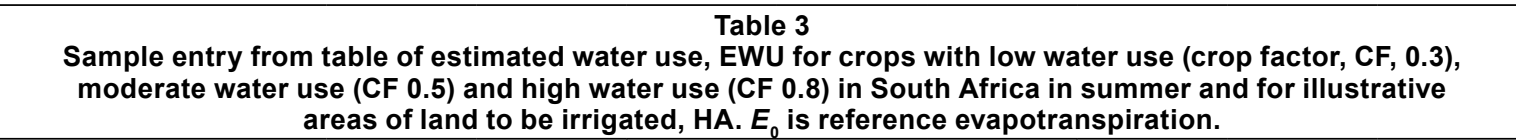 } \\
\hline \multirow[b]{2}{*}{$\begin{array}{l}\text { Climatic region, province, } \\
\text { representative weather } \\
\text { station }\end{array}$} & \multirow[b]{2}{*}{$\underset{E_{0}}{\text { Summer }}$} & \multirow[b]{2}{*}{$\begin{array}{c}\text { Crop } \\
\text { factor (CF) }\end{array}$} & \multicolumn{3}{|c|}{$\begin{array}{c}\text { EWU in } \ell \cdot d^{-1}, \text { summer; } \\
\text { applicable to irrigated area (HA) of: }\end{array}$} & \multicolumn{3}{|c|}{$\begin{array}{c}\text { EWU in } \ell \cdot \text { week }^{-1} \text {, summer; } \\
\text { applicable to irrigated area (HA) of: }\end{array}$} \\
\hline & & & $5 \mathrm{~m}^{2}$ & $10 \mathrm{~m}^{2}$ & $20 \mathrm{~m}^{2}$ & $5 \mathrm{~m}^{2}$ & $10 \mathrm{~m}^{2}$ & $20 \mathrm{~m}^{2}$ \\
\hline \multicolumn{9}{|l|}{ Hot and arid } \\
\hline \multirow{3}{*}{$\begin{array}{l}\text { Northern Cape } \\
\text { Upington }\end{array}$} & 12.7 & 0.3 & 19 & 38 & 76 & 133 & 267 & 533 \\
\hline & 12.7 & 0.5 & 32 & 64 & 127 & 222 & 445 & 889 \\
\hline & 12.7 & 0.8 & 51 & 102 & 203 & 356 & 711 & 1422 \\
\hline \multirow[t]{3}{*}{ Okiep } & 10.7 & 0.3 & 16 & 32 & 64 & 112 & 225 & 449 \\
\hline & 10.7 & 0.5 & 27 & 54 & 107 & 187 & 375 & 749 \\
\hline & 10.7 & 0.8 & 43 & 86 & 171 & 300 & 599 & 1198 \\
\hline \multirow[t]{3}{*}{ Calvinia } & 6.2 & 0.3 & 9 & 19 & 37 & 65 & 130 & 260 \\
\hline & 6.2 & 0.5 & 16 & 31 & 62 & 109 & 217 & 434 \\
\hline & 6.2 & 0.8 & 25 & 50 & 99 & 174 & 347 & 694 \\
\hline \multirow{3}{*}{$\begin{array}{l}\text { North West } \\
\text { Mafikeng }\end{array}$} & 9.4 & 0.3 & 14 & 28 & 56 & 99 & 197 & 395 \\
\hline & 9.4 & 0.5 & 24 & 47 & 94 & 165 & 329 & 658 \\
\hline & 9.4 & 0.8 & 38 & 75 & 150 & 263 & 526 & 1053 \\
\hline
\end{tabular}

exception of E. coli, as discussed above). Furthermore, the guidance specifies that where extensive or high-technology treatment would be required to make greywater suitable for irrigation use of any kind, then off-site disposal would be likely to be a safer and cheaper option.

\section{Greywater quality: Mitigation of greywater quality}

Suggested mitigative practices (DWAF, 1996) address:

- Irrigation method, with subsurface application being the preferred method

- Amelioration of soil, e.g. by addition of mulch or gypsum to soil. Kaolinite has also recently been shown to improve soil degraded by long-term application of wastewater (Matiax-Solera et al., 2011)

- Leaching of soil to remove excess salt, by application of excess water, preferably, freshwater. This must be balanced against the risk of contaminating surface water or groundwater, depending on local conditions.

- Planting of tolerant plant types, particularly plants tolerant of sodium or boron

- Miscellaneous irrigation modifications

- Accepting reduced crop yield

Treatment options included in the guidance report were:

- Mulch tower (separate from irrigation application)

(Ridderstolpe, 2007; Whittington-Jones, 2007)

- Mulch tower and resorption bed (separate from irrigation application or can be integrated) (Ridderstolpe, 2007; Whittington-Jones, 2007)

- Various forms of tower or tube gardens (integrated with irrigation application) (Crosby, 2005; Alcock, 2009)

A number of general recommendations arose from discussions of the project team and reference group, based on the reviewed literature and on collective experience. These recommendations apply irrespective of the treatment system used. Greywater-treatment systems should be sufficiently simple and robust to function effectively in rural and peri-urban settlements, preferably without power or piped water and with minimal technical expertise required for maintenance. Treatment systems should use the simplest and most cost-effective technology required to meet the water-quality objectives. Any system which is implemented should be thoroughly tested and proven before implementation to avoid user fatigue caused by system failure and ongoing changes (Ridderstolpe, 2007).

\section{Greywater quantity: Guide to irrigation volumes}

This section was developed to provide general guidance in selecting the volume of greywater which could be applied to a garden or to small-scale crop cultivation. The aim was not to provide detailed technical specification of irrigation planning and management, but rather to offer broad guidance regarding the types of considerations which govern the amount of greywater which can be applied. The guidance should be used in the context of existing knowledge of good irrigation and plantcultivation practices. As for previous sections, guidance was given within the context of the overall aims of minimisation of risks to human health, to plant/crop growth and yield, and to soil fertility.

A sample entry from the table of estimated maximum irrigation volumes $(E W U)$ given in the Guidance Report, is presented in Table 3.

To be useful specifically for greywater application, it was necessary to provide some means of making the estimation of $E W U$ sensitive to site-specific factors likely to dominate irrigation conditions in a residential or food garden. Qualitative advice was provided for greywater-application frequency and rate on different soil types. Soils containing a high proportion of sand typically have a high infiltration rate (USDA, 1998) and require more frequent application of small volumes of greywater. Soils containing a high proportion of clay typically have a low infiltration rate and a high capacity to store water (USDA, 1998), thus are more suited to a slower application rate or to use of structures such as infiltration basins around the bases of plants to prevent surface runoff. While it is acknowledged that this guidance 
takes only superficial cognisance of soil composition, it was intended that it should be accessible even to unsophisticated users with minimal knowledge of soils. Numerical factors were provided to adjust $E W U$ for crop coverage (Green, 1985). Account was taken of recent rainfall by subtracting the amount of rain in the previous $24 \mathrm{~h}$, where $1 \mathrm{~mm}$ of rainfall was considered equivalent to $1 \ell$ of water per square meter. In cases of continuous rainfall over a period longer than $24 \mathrm{~h}$, the amount of rainfall over the total period of rain should be discounted. These steps, together, allow $E W U$ to be adjusted for site-specific factors.

It is acknowledged that this approach did not take into account the best that science can offer for irrigation-water planning (e.g. using the Penman-Monteith equation for calculation of $E_{0}$ in place of point estimates, or using the SAPWAT model for irrigation planning - SAPWAT, 2009). Instead, it took cognisance of the need for guidance to be simple enough for relatively unsophisticated users to apply.

\section{Challenges to sustainable use of greywater for small-scale irrigation}

Challenges to the uptake of greywater irrigation by users exist at a number of levels.

\section{National government}

Currently, greywater use falls outside the framework of existing laws governing water and wastewater. The legal status of greywater use in terms of the NWA and NBR needs to be clarified at national level.

\section{Municipalities}

A major and very concerning finding from the consultation phases of this project was a lack of awareness and capacity among municipalities with respect to greywater. Response rates to calls for consultation and feedback were typically below $10 \%$ after follow-up and most responses received indicated a substantial lack of understanding of greywater and of related issues. There is an urgent need for capacity building at local authority (municipal) level with respect to knowledge of greywater issues, in general, and of the potential of greywater use for irrigation, in particular.

A prerequisite for successful implementation is that potential irrigation users of greywater are involved in the planning and execution of projects, and are educated on the risks, benefits and proper handling of greywater, of irrigated land and of greywaterirrigated crops. This is especially true in low-income settlements where the challenges and barriers to greywater use are greatest.

Probably the greatest potential for greywater use lies in including greywater collection, treatment and use in the planning of new settlements or alterations to existing housing developments. However, it is important to ensure that the greywater technologies introduced have been proven to be sound; that designs are implemented correctly; and that housing management and users are committed to using the facilities properly. Failure in any of these areas has been shown to lead to failure of greywater-use projects (Ridderstolpe, 2007; Whittington-Jones and Tandlich, 2010).

\section{Informal settlements}

Winter et al. (2011) described the extensive challenges facing implementation of greywater management projects in underserviced low income areas. While informal settlements are, in principle, among those urban and peri-urban settlements which could stand to benefit particularly from greywater use for irrigation, there are many barriers which have little to do with greywater per se. Greywater initiatives in such settlements require concerted up-front input by the local authority to provide a receptive environment. This may appear to be a bleak outlook, particularly in light of capacity problems at municipal level already mentioned. However, preliminary experiences in eThekwini Municipality (described in Rodda et al., 2010b) have shown it is possible, given political will, focused policies and co-operation with outside consultants with both social and technical expertise.

\section{Conclusions and recommendations}

Irrigation is a potential beneficial use of greywater which can conserve freshwater resources and improve quality of life. The guidance developed in this study represents an important contribution to initiation and management of greywater irrigation implementations in South Africa. Unlike existing South African guidelines for water quality for irrigation (DWAF, 1996), these guidelines are specific to greywater use and to small-scale irrigation. Unlike guidelines for greywater irrigation from other countries, such as Australia (EPA Victoria, 2008), USA (Little, 2001), Sweden (Ridderstolpe, 2004) and Jordan (CSBE, 2003), these guidelines are specific to South African conditions, being based on South African studies of greywater (Murphy, 2006; Carden et al., 2007; Rodda et al., 2010b), South African water quality guidelines (DWAF, 1996) and South African climatic and agricultural data (Green, 1985; Blignaut et al., 2009). The latest WHO guidelines (WHO, 2006), although comprehensive and adaptable to local conditions, address primarily minimisation of human health risks, and therefore do not extend to all the underlying principles set for this study. By addressing greywater quality and quality mitigation, risk management and irrigation water quantity, the guidance presented here places greywater irrigation in a broader context than do most existing greywater irrigation guidelines, even though coverage is not as comprehensive for any single topic as, for instance, the WHO guidelines for health risk (WHO, 2006).

The following are necessary to facilitate greywater use in South Africa:

- Enshrining greywater use as a permitted water use in relevant legislation at national level

- Capacity building at provincial and municipal level

- Educating potential users at settlement or household level, and involvement of potential users in planning greywateruse projects at municipal level

- Integration of greywater-use provisions in new developments at municipal level

- Municipal and provincial authorities developing an enabling environment in low-income settlements through:

- Building a sense of community

- Improving communication between authorities and settlement representatives

- Providing infrastructure for water, sanitation, wastewater and solid waste

- Providing infrastructure and guidance for greywater use in exchange for some form of incentive scheme.

\section{Acknowledgements}

This work was funded by the Water Research Commission. Supporting studies were co-funded by the eThekwini 
Municipality, the National Research Foundation and the Stockholm Environment Institute. The excellent support given by the reference group for this project is gratefully acknowledged.

\section{References}

ALCOCK N (2009) Personal communication by letter from N Alcock, Khanyisa Projects, to T. Gounden, eThekwini Water and Sanitation, eThekwini Municipality, Durban, South Africa.

BENNET D (1995) Graywater, an option for household water reuse. Home Energy Magazine Online July/August 1995. URL: http:// www.homeenergy.org/archive/hem.dis.anl.gov/eehem/95/950712. html (Accessed October 2010).

BLIGNAUT J, UECKERMANN L and ARONSON J (2009) Agriculture production's sensitivity to changes in climate in South Africa. S. Afr. J. Sci. 105 61-68 and online supplementary material.

CALIFORNIA BUILDING STANDARDS COMMISSION (2010) 2010 California Plumbing Code, California Code of Regulations, Title 24, Part 5. URL: http://www.archive.org/stream/gov.ca.bsc. title24.2010.part05/ca 2010 title24 05\#page $/ \mathrm{n} 0 / \mathrm{mode} / 2 \mathrm{up}$ (Accessed March 2010).

CARDEN K, ARMITAGE N, SICHONE O and WINTER K (2007) The Use and Disposal of Greywater in the Non-Sewered Areas of South Africa. WRC Report No. 1524/1/07, Water Research Commission, Pretoria, South Africa. 242 pp.

CORDELL D, DRANGERT JO and WHITE S (2009) The story of phosphorus: global food security and food for thought. Global Environ. Change 19 292-305.

CROSBY C (2005) Food from used water, making the previously impossible happen. The Water Wheel, January/February 2005, $10-13$.

CSBE (2003) Graywater Reuse in Other Countries and its Applicability to Jordan. Center for the Study of the Built Environment, Amman, Jordan. URL: http://www.csbe.org/graywater/report/ report final.pdf (Accessed June 2008)

DANIELS D, DANIEL T, CARMAN D, MORGAN R, LANGSTON J and VANDEVENDER K (2011) Soil Phosphorus Levels: Concerns and Recommendations. University of Arkansas, Department of Agriculture Cooperative Extension Service. URL: http:/www. sera17.ext.vt.edu/Documents/Soil_P_Levels_Concerns_and Recommendations.pdf (Accessed January 2011).

DEPARTMENT OF NATIONAL HEALTH AND POPULATION DEVELOPMENT (1978) Guide: Permissible Utilisation and Disposal of Treated Sewage Effluent, Reference No. 11/2/5/3. Department of National Health and Population Development, Pretoria, South Africa, $11 \mathrm{pp}$.

DWAF (1996) South African Water Quality Guidelines (SAWQG), $2^{\text {nd }}$ edition, Volume 4: Agricultural Water Use: Irrigation. Department of Water Affairs and Forestry, Pretoria, South Africa. 194 pp.

DWAF (2003) Water is Life, Sanitation is Dignity, Strategic Framework for Water Services. Department of Water Affairs and Forestry, Pretoria, South Africa. 73 pp.

DWAF (2004) Revision of General Authorisations in Terms of Section 39 of the National Water Act, 1998 (Act No. 36 of 1998). Government Gazette No. 26187, Government Notice No. 339, Department of Water Affairs and Forestry, Pretoria, South Africa.

EPA VICTORIA (2008) The Do's and Don'ts of Reusing Greywater. EPA Victoria, Publication No. 884, State of Victoria. URL: http:// epanote2.epa.vic.gov.au/EPA/Publications.NSF (Accessed January 2010).

ERIKSSON E, AUFFARTH K, HENZE M and LEDIN A (2002) Characteristics of greywater. Urban Water 4 85-104.

GRAVELE'T-BLONDIN LR (2010) Personal consultations with LR Gravele't-Blondin, Water Lily Consulting, Durban, South Africa. (LR Gravele't-Blondin previously of Department of Water Affairs and Forestry).

GREEN GC (editor) (1985) Estimated Irrigation Requirements of Crops in South Africa, Parts 1 and 2. Memoirs on the Agricultural Natural Resources of South Africa, No. 2. Soil and Irrigation Research Institute, Department of Agriculture and Water Supply, Pretoria, South Africa. 857 pp.
JACKSON SAF, MUIR D and RODDA N (2010) Use of domestic greywater for small-scale irrigation of food crops: health risks. Proc. $11^{\text {th }}$ Waternet/WARFSA/GWP-SA Symposium, 27-29 October, Victoria Falls, Zimbabwe.

JACKSON SAF, RODDA N and SALUKAZANA S (2006) Microbiological assessment of food crops irrigated with domestic greywater. Water SA 32 700-704.

LITTLE V (2004) Residential Graywater Reuse Fact Sheet. Water Conservation Alliance of Southern Arizona. Arizona Department of Water Resources. URL: http://www.watercasa.org/pubs/graywaterguidelines.html (Accessed November 2009).

MATIAX-SOLERA J, GARĆIA-IRLES L, MORUGÁN A, DOERR SH, GARCIA-ORENES F. ARCENEGUI V and ATANASSOVA I (2011) Longevity of soil water repellency in a former wastewater disposal tree stand and potential amelioration. Geoderma. DOI: 10.1016/j.geoderma.2011.07.006.

MOREL A and DIENER S (2006) Greywater Management in Low and Middle-Income Countries, Review of Different Treatment Systems for Households or Neighbourhoods. Swiss Federal Institute of Aquatic Science and Technology (EAWAG), Dübendorf, Switzerland. $107 \mathrm{pp}$.

MURPHY KO'H (2006) A Scoping Study to Evaluate the FitnessFor-Use of Greywater in Urban and Peri-Urban Agriculture. WRC Report No. 1479/1/06. Water Research Commission, Pretoria, South Africa. 143 pp.

NAICKER P, SMITH MT, RODDA N, JONSSON H and RIDDERSTOLPE P (2010) Evaluation of an onsite biological greywater treatment system when exposed to different loading scenarios. Proc. Biennial Conference of the Water Institute of South Africa, 18 to 21 April, Durban, South Africa.

NATIONAL BUILDING REGULATIONS AND BUILDING STANDARDS ACT (1977) Act No. 103 of 1977. Republic of South Africa. URL: http://www.capetown.gov.za/en/planningandbuilding/Functions/Documents/National_Building_Regulations and_Building_Standards_Act_No_103 of 1977.pdf (Accessed November 2009).

NATIONAL WATER ACT (1998) Act No. 36 of 1998. Republic of South Africa. URL: http://www.dwaf.gov.za/Documents/ Legislature/nw act/NWA.pdf (Accessed November 2009).

RESOLVE CONSULTING (2010) Guidelines for Water Use Efficiency on Commercial, Institutional and Residential Properties. Technical Report prepared by Re-Solve Consulting (Pty.) Ltd. for eThekwini Municipality, Durban, South Africa.

RIDDERSTOLPE P (2004) Introduction to Greywater Management. EcoSanRes Programme, Stockholm Environment Institute, Stockholm, Sweden. 24 pp.

RIDDERSTOLPE P (2007) Mulch Filter and Resorption Trench for Onsite Greywater Management. Report for a demo facility built in Kimberley, South Africa. EcoSanRes Programme, Stockholm Environment Institute, Stockholm, Sweden. 27 pp.

RODDA N, CARDEN K and ARMITAGE N (2010a) Sustainable Use of Greywater in Small-scale Agriculture and Gardens in South Africa, Guidance Report. WRC Report No. TT 469/10. Water Research Commission, Pretoria, South Africa. 100 pp.

RODDA N, CARDEN K and ARMITAGE N (2010b) Sustainable Use of Greywater in Small-scale Agriculture and Gardens in South Africa, Technical Report. WRC Report No. 1639/1/11. Water Research Commission, Pretoria, South Africa. 283 pp.

RODDA N, SALUKAZANA L, JACKSON SAF and SMITH MT (2011) Use of Domestic Greywater for Small-scale Irrigation of Food Crops: Effects on Plants and Soil. J. Phys. Chem. Earth. DOI: 10.1016/j.pce.2011.08.002.

ROESNER L, QIAN Y, CRISWELL M, STROMBERGER M and KLEIN S (2006) Long-Term Effects of Landscape Irrigation using Household Greywater: A Literature Review and Synthesis. Water Environment Research Foundation (WERF) and Soap and Detergent Association (SDA), Washington DC, USA. 82 pp.

SAPWAT (2009) SAPWAT Website. Water Research Commission, Pretoria, South Africa. URL: http://sapwat.org.za (Accessed November 2009).

SCHULZE RE (1997) South African Atlas of Agrohydrology and Climatology. WRC Report No. TT 82/96. Water Research 
Commission, Pretoria, South Africa. 276 pp.

SIGUA GC, HUBBARD RK and COLEMAN SW (2010) Quantifying phosphorus levels in soils, plants, surface water and shallow groundwater associated with bahiagrass-based pastures. Environ. Sci. Pollut. Res. Int. 17 (1) 210-219.

STANDEN R and McGUCKIAN R (2000) Developing irrigation guidelines for wastewater irrigation. Proc. 63 ${ }^{\text {rd }}$ Annual Water Engineers and Operators Conference, 6-7 September, Warrambool, Australia.

TRAVIS MJ, WEISBROD N and GROSS A (2008) Accumulation of oil and grease in soils irrigated with greywater and their potential role in soil water repellency. Sci. Total Environ. 394 68-74.

UNKOVICH M, STEVENS D, YING G and KELLY J (2004) Impacts on Crop Quality from Irrigation with Water Reclaimed from Sewage. Australian Water Conservation and Reuse Research Program, Australia. 62 pp.

USDA (1998) Soil Quality Indicators: Infiltration. United States Department of Agriculture, Natural Resources Conservation Services. URL: http://soils.usda/sqi/assessment/assessment. html\#indicator sheets (Accessed August 2009).

VAN AVERBEKE W (2007) Urban farming in the informal settlements of Atteridgeville, Pretoria, South Africa. Water SA 33 337-342.
VAN AVERBEKE W, JUMA KA and TSHIKALANGE TE (2007) Yield response of African leafy vegetables to nitrogen, phosphorus and potassium: the case of Brassica rapa L. subsp. chinensis and Solanum retroflexum Dun. Water SA 33 355-362.

WHO (2006) Guidelines for the Safe Use of Wastewater, Excreta and Greywater. World Health Organisation, Geneva, Switzerland. 144 pp.

WHITTINGTON-JONES K (2007) Construction of Grey Water Treatment Systems for the Scenery Park (Buffalo City Municipality) Pilot Project, Phase 2 Report. Report prepared for EcoSanRes and the Stockholm Environment Institute by Scarab Resource Innovations. South Africa. 14 pp.

WHITTINGTON-JONES KJ and TANDLICH R (2010) Performance of Pilot Biological Grey Water Treatment Systems in Scenery Park (Buffalo City Municipality, South Africa). Report prepared for the Stockholm Environment Institute and EcoSanRes. 22 pp.

WINBLAD U and SIMPSON-HÉBERT M (2004) Ecological Sanitation - Revised and Enlarged Edition. Stockholm Environment Institute, Stockholm, Sweden. 147 pp.

WINTER K, SPIEGEL A, ARMITAGE N and CARDEN K (2011) Sustainable Options for Community Level Management of Greywater in Settlements Without On-Site Waterborne Sanitation. WRC Report No. 1654/1/11. Water Research Commission, Pretoria, South Africa. 143 pp. 
http://dx.doi.org/10.4314/wsa.v37i5.10 Available on website http://www.wrc.org.za

ISSN 0378-4738 (Print) = Water SA Vol. 37 No. 5 WRC 40-Year Celebration Special Edition 2011 ISSN 1816-7950 (On-line) = Water SA Vol. 37 No. 5 WRC 40-Year Celebration Special Edition 2011 